\title{
Leadership in Public and Private Higher Institutions of Learning in Uganda: A Case Study of the Eastern Region
}

\author{
Article by Henri Buregea Bin Rwakenda \\ PhD, Texila American University \\ E-mail: henry.buregea@livingstone.ac.ug
}

\begin{abstract}
Education a crucial domain of life indispensable for long-lasting development. Government and schools in Uganda have made a great effort to develop the education sector in Uganda. Employment is scarce. Students who get jobs seems not be full prepared for them. Society and especially business owners have identified graduates to be half baked failing to meet job expectations. Despite their effort, available opportunities and potentials are not yet fully explored. Besides that, there are also challenges that leaders of Schools face in their day-to-day operations which hinder them to fully lead higher Institutions of Learning (HILs) to the fulfillment of their missions and visions. Alongside those challenges, opportunities and potential do exist. The research paradigm of the study was pragmatic leadership theory that leads to self-reliance indispensable for transformational development. The aim of the research was to use this theory to develop another theory. This could help address issues of unemployment because of the poor quality of graduates upon completion of their studies. The population of the study were leaders of HILs that are accredited and in operation in the Eastern Region of Uganda for at least five years. The sampling technique was purposive and convenient in nature. The research method was qualitative. The instruments used were In-depth Interview (IDI) and Focus Group Discussions (FGDs). Interview and moderator guides were used. Data collected were categorized and data were analyzed and classified; opportunities, potentials as well as challenges were reported. A new theory was developed and areas for further studies proposed.
\end{abstract}

Keywords: School Leadership, Higher Institution of Learning, Leadership opportunity, Leadership Potential, Leadership Challenge, Integral Development, Total transformation.

\section{Introduction of the study}

Education is a highway for development. The prerequisites for a successful economic development program have been said to be a "substantial degree of literacy" and an educated elite of substantial size (Galbraith, 1961). King (2004) indicates that his vision of development is self-reliance. For education to reach that vision, its leadership should focus attention to design educational curriculum meant to achieve development. Presumably development brings about a resource base that can lead to the improvement of the lot of human beings so that they can have access to knowledge and opportunity and so fulfill their human potential in a better world (Galbraith, 1961). He further says that economic development can be both a prerequisite and a consequence of it (Ibid.). He indicates that:

A certain kind and quantity of education must be regarded as a necessary input to achieve rising growth rates. This is true not only in terms of the achievement of higher rates of literacy, but also in terms of specific vocational training and training for intermediate and higher administrative and managerial positions. The problem then, is not whether education is a prerequisite for economic growth, but rather, the questions that needs to be asked are what kinds of education at what levels, in what quantities, how should education be organized, and how can education be best administered?

However, there are lots of factors that may come into play as development and self-reliance are targeted. Since the Ugandan education system was inherited from the British system, there is a need to rethink the education system in Uganda. The notion of education brings with it the need for effective leadership. As they get trained, students need School leaders who expose them to life reality and challenge them to use 
their full potential to adapt and adjust to the demands of society and community where they are to live. Bright future means self-reliance. Self-reliance is not possible if there is no development as a consequence of it.

Development must emphasize employment, income distribution, self-reliance and commitment (op. Cit.). One disturbing dilemma that many developing countries, especially those in Africa are faced with, is that they have invested enormous sums of money in education since they have achieved independence, but the long-awaited economic growth has not yet occurred (Galbraith, 1961). Economic growth remains a myth because most of those who graduate are either jobless, hence not productive as society expects. Unfortunately, Statistics show that employments are very rare to the African graduate and worse in Uganda. The Guardian indicates that, "Youth unemployment in Uganda is the highest in Africa". A recent publication "Lost opportunity? Gaps in youth policy and programming in Uganda", published by ActionAid, put youth unemployment at 62\%, although the African Development Bank says it could be as high as $83 \%$ (Ibid.). Unemployment is a social situation that gives a way for training the youth to fight it and make them able to be job creators rather than job seekers. Statistics show that there is job scarcity in Uganda. The Vice Chancellor's Forum (2016) indicates that more than 400.000 Students (who) graduate from Higher Institutions of Learning but only 150.000 get jobs.

This situation is worrying in case nothing is done to help reverse the situation. The call is for those in charge of education, politics, and development. It is more than urgent therefore that HILs organize an education system that will promote job creation for wealth creation. Galbraith (1961) posits that Education has until recently been neglected in the study of economic development. Education has been regarded as a consumption good, is now also recognized as an investment and a direct contribution to increased economic productivity in much the same way that capital and machinery is recognized (Ibid). For this reason, the educational goals set in HILs should lead to decisions that prompt for not only knowledge but training in relevant skills and should involve different stakeholders. In relation to this, Harvard University (2012) says:

Leaders do not make decisions in isolation nor are the implications of their decisions inconsequential. Leaders make decisions with others (either for others, against others, or with others in mind) with the goal of changing that social context, ideally for the "better," but often with the risk that their decisions may have negative effects or collateral implications.

For this to happen, the school leader of today must play a panoply of roles, engage in a plethora of activities, and make a myriad of decisions to ensure student learning. The list of roles and responsibilities is vast and overwhelming (2008). But which roles do new leaders most frequently play? Are these roles chosen or assigned? How do new leaders learn to play the roles they are uncomfortably playing? How do they learn to authentically inhabit the role of the school leader? By looking at the frequency of roles described in administrative narratives, one begins to get a picture not only of the concerns and challenges that new administrators face but also of their corresponding priorities and underlying values (Op. cit.). As leaders in HIL and Eastern Region Local Government (ERLG) have priorities and values that guide their leadership, all those priorities and values were looked at from a transformational and pragmatic research paradigm. Musaazi (2006) indicates that to make education a profitable enterprise and a contributor to social development, planning must come to be accepted as the essential prerequisite. With education comes the need for effective leadership especially at Higher Education level. It is within schools that the minds of people are shaped and trained in favor of development in different sectors of society.

\section{Background of the study}

Rapid, sweeping and long-lasting change is altering our planet environment in and unprecedented manner, while societies are undergoing profound shifts in their demographic makeup and social economic fabrics. Political agreements, financial incentives or technological solutions alone do not suffice to grapple with the challenges and demands of sustainable development. It will require a wholesale change in the way we think and the way we act- a rethink of how we relate to one another and how we interact with the ecosystems that support our lives (UNESCO, 2014). 
To create a world that is more just, peaceful and sustainable, all individuals and societies must be equipped and empowered by knowledge, skills, and values as well as be instilled with heightened awareness to drive such a change (Ibid.). Because of this, the model we are going to use to guide this research is from a pragmatic paradigm dimension of research for positive transformation. Effective leadership should lead to intentional practical application of knowledge for both individual and collective transformation.

To achieve genuine, sustainable results, leaders in the "Pragmatic leadership" Program are exposed to six different learning dynamics, which, when combined, influence and enable meaningful, longer-term growth (www.pragmaticleadership.ca).

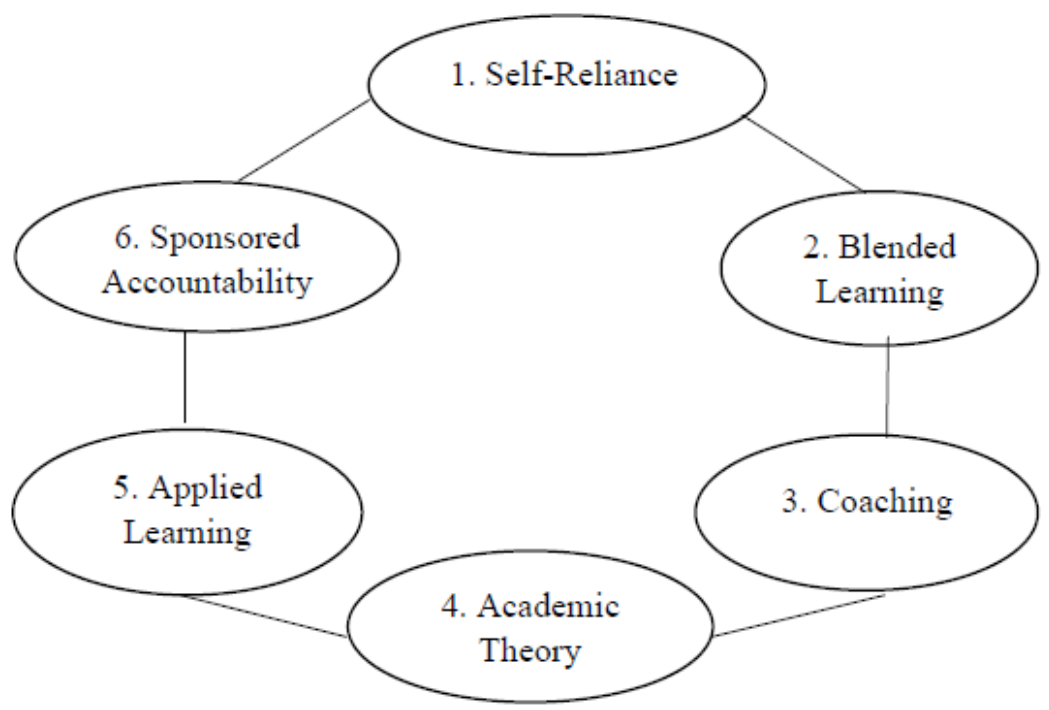

Figure 2. Pragmatic leadership theory

Before leading others, learners must first develop the tools to lead themselves. This process begins with the leadership circle profile, which delivers insights into a learner's current proficiency in creative competencies and provide an awareness of their reactive tendencies. These insights inform the learner's development agenda and opportunities throughout the program (www.pragmaticleadership). With Blended Learning, Great leaders can adapt to changing environments. Program learners will be exposed to a combination of online self-study and group discussion, as well as in-class learning. Learners must be selfmotivated to complete study requirements and pursue interaction with cohort members (Ibid.) Coaching is highly effective for helping learners maintain accountability and clarity of their goals...

Practice makes progress. Learners complete a series of field assignments throughout the program, as well as a three-to-six months workplace Learning Development Initiative (LDI) after the program, Practicing the skills they have learned in a real-world context, learners must assess a given situation, identify opportunity for growth, set a vision, and achieve the desired outcome (Ibid.). Having someone else's support can have a powerful effect on personal growth. Learners will have an executive sponsor sign off on their final Leadership development Initiative. This institutional accountability and sponsorship increase the learner's potential to achieve observable and meaningful growth in their leadership and workplace effectiveness (Ibid.).

\section{Literature review}

\section{Leadership opportunities in higher institutions of learning}

There is an urgent need to study leadership setting especially in HILs and assess how people and systems are influenced. HILs offer a more reliable platform to exercise leadership. Both students and staff in such institutions can be taught and practice leadership. Topping (2002) says, 
DOI: $10.21522 /$ TIJAR.2014.SE.19.01.Art007

ISSN: $2520-3088$

If we can teach them how to be more effective leaders, even very modest improvements in each person can reap big rewards for the entire organization. So, can leadership be taught? Not in the way we can teach mathematics or discounted cash flow, but a heightened understanding of how leadership behaviors affect others and impact performance can help anyone enhance his or her effectiveness. And isn't any gain in this area worth the effort?

There is no doubt that there is gain in perspective. What is important is to see what is happening and consider it as an opportunity to learn and analyze the situation and make necessary adjustments for change. But it is important to know that, in the world, "All organizations throughout history have needed and displayed varying levels of success with their own leadership. And the world does not just consist of Europe and America. Leadership was, is, and always will be a global issue, one which involves all people, whatever their organizational or social setting (Hooper and Potter, 2001). From a global education perspective, efforts have been made to help countries in the developing world. It is one thing to help a country deliver the right to basic education; it is quite another thing to agree to help secure that right for the foreseeable future (King, 2004).

For this future to be great, there should be leadership opportunities that have to be seen by leaders at different levels of social interaction especially leaders in HILs and political and administrative leaders of both national, regional and local government. In Africa, Musaazi (2011) indicates that the sociopolitical objectives of Education in Nigeria, Uganda, and Kenya are relatively unformulated beyond vague invocations to educational institutions to promote democracy, egalitarianism, self-reliance, respect for dignity of labor and to adopt a rural orientation and to install nationalism. The education system in any country should consider what Musaazi is indicating here. A lot needs to be done to better the education system in Africa if we truly need to lead true democracy, egalitarianism, self-reliance, respect for dignity of labor to adopt rural orientation and to install nationalism.

Uganda as a country is aware of that change and is making necessary efforts to improve the quality of leadership and education in HILs. HILs are frequently challenged by education officials. It is time for policy makers to revisit their mission, practices and operational models to comply with set standards for quality assurance that will allow Africa and Uganda in to be effective catalysts of educational dynamics as far as globalization and its effects on education and development are concerned.

Another factor to be considered as a leadership opportunity is the population explosion which leaves behind a high percentage of the youth. Uganda is very particular in this because its population is predominantly young. The guardian (2014) reveals that Uganda has the world's largest percentage of young people under 30 making $78 \%$ of the population according to the 2012 State of Uganda population report by the UN Population Fund (Ibid.).

In the past decade, Uganda has experienced strong Growth Domestic Product (GDP) growth, averaging $7 \%$ annually, but this has not generated jobs, a trend seen across the continent. The lack of employment is causing some young people to take deadly risks. Last July, 36 young people, who had been running motorcycle taxis, were burnt to death as they tried to siphon fuel from a truck that had been involved in an accident (The Guardian 2014). Some young women are taking jobs overseas only to find themselves forced into prostitution, according to Uganda police. "Every month, we get reports of over 20 Ugandans stranded seeking help. If the figure is multiplied in a year, it comes to over 250 Ugandans stranded abroad every year," says Moses Binoga, Coordinator of the Anti-Human Trafficking National Task Force (Ibid).

Other young people are involved in drug trafficking. Dr. Paul Nyende, a Senior Lecturer at Makerere University's School of Psychology, says young people with nothing to do are more easily lured into crime. "They can easily be lured into drug trafficking on promise of big pay," he says. "Many young people don't want to go back to the villages and do farming after campus. They want to stay and enjoy city life." (Ibid). Yet the city cannot support them. It is estimated that more than 40,000 young people graduate from Ugandan universities each year. Yet the market can provide only 8,000 jobs annually (Ibid).

The same report indicates that worldwide, there are about 1.2 billion 15- to 24-year-olds. About 200 million are in Africa. This portion of the world's population needs to be considered as a reliable springboard 
for sustainable development for the world but more urgently for developing countries, Uganda included. In Uganda for example, the National Council for Higher Education (NCHE) has developed a Quality Assurance framework to help HILs maintain quality. In this framework proper standards have been set to guide HILs to focus on what is required to meet the expectations of the Ministry of Education and Sports (NCHE Quality Assurance Framework, 2011). In line with this, Uganda has established the Uganda University Quality Assurance Forum (UUQAF). This Forum is meant to promote quality Education and appropriate school leadership for more efficiency and efficacy. This is a great opportunity for appropriate leadership in HILs in Uganda. Globalization, Partnerships, freedom of thoughts, the youth population and unemployment must be taken as opportunities to rethink leadership in HILs and see what these institutions and government organizations at all levels (national, regional, and local) can do to develop curricula that promote need-based knowledge, appropriate skills, and research oriented to community problems and issues that must be urgently addressed.

\section{Leadership potentials in higher institutions of learning}

School Leadership cannot be developed apart from the existing population and the country's general resources. According to UBOS 2014, Uganda has a population of 34. 85 Million. Life expectancy in Uganda is 58.65 years (https://www.google.com/\#q=uganda+population). It is also known that the Ugandan population is dominated by youths representing around $78 \%$ of the total population as initially pointed out. These statistics are very significant for school leadership. In them lies, a great potential for school leadership empowerment on which depends the future of the education sector for integral development.

Uganda has quite several natural resources that the youth can be exposed to. With adequate training, skills and appropriate technologies, they can be helped to gain insights to use all those resources according to their individual giftedness that could lead to the betterment of their lives. There are institutions in Uganda in general and in Eastern Region particularly which target to train future leaders because they have realized that there is potential in the youth. One of these institutions is Cornerstone Leadership Academies-Uganda who aims at molding young people coming from disadvantaged backgrounds, but with high potential - into future leaders (Cornerstone Leadership Academy, 2013).

Unemployment is another social situation that gives potential for training the youth to fight it and make them able to be job creators than job seekers. In fact, statistics show that there is job scarcity in Uganda. The Vice Chancellor's Forum (2016) indicate that more than 400.000 Students graduate from Higher Institutions of Learning but only 150.000 get jobs. Apart from these academies you have other projects that focus on the economic potential of different communities. In Eastern Region, you have groups like Transforming Community Initiatives (TCI) (https://www.csrmatch.org).

Such organizations can work with HILs so that communities with special initiatives can be equipped with more knowledge through capacity building to sustain those initiatives and maintain and increase growth. In fact, knowledge accumulation in all countries depends on steady investments to increase science education as well as to improve the Science, technology, Innovation (STI), policy environment to foster endogenous innovations, through all means of learning, including research and development (UN Post 2015 Development Agenda). Unemployment is a great potential for transformative education that leads to creativity and job creation.

\section{Leadership challenges in higher institutions of learning}

Hans (1994) posits that Leadership is dangerous. He says that, World history can be best be written by studying the lives of great and terrible leaders and what they accomplished through others. We who are in leadership can on the one hand move men, women, and mountains for tremendous good. At the same time, we hold in our hands the power to do irreparable damage to our followers by the mistakes we made.

Most leaders do not accept or easily admit that they make mistakes. The fact of one ignoring his or her own mistakes is a big challenge to effective leadership. This is a reality that concerns almost all organizations globally, regionally and locally. HILs in Uganda and Eastern Region Local Government are included. In addition to one not accepting his or her mistakes, other factors challenge significantly 
DOI: 10.21522/TIJAR.2014.SE.19.01.Art007

ISSN: $2520-3088$

leadership. These include personality traits, school of thoughts, purposes of organizations, political, economic, social and cultural dynamics in the country, etc.

In South Africa for example, Shivambu (2015) indicates that the students' protests around the country give us cause to reflect on the politics behind the higher education funding crisis in South Africa. He also points out that, "Students with affiliations to different political parties are at the forefront of the protests, and the demands are centered on securing no fee increases for the academic year 2016, and variety of genuine worker demands (Ibid.) So political dynamics in a country is one of the challenges that affect both schools and District leaderships here and there. Shivambu further denounces other challenges such as the failure of the education systems to address students' demands and the lack of will evident in parliament.

Another area that challenges HILs is the advancement in the Information technology sector and its impact on education especially at these initial stages of development in the $21^{\text {st }}$ Century. The impact on school leadership is felt. In relation to this, Ali, Haolader, Muhammad (2013) say that, "The effective integration of technology into classroom practices poses a challenge to teachers and administrators" This is crucial for globalization to have a positive impact in Uganda and in Eastern Region in particular. An average leader faces at least five problems in learning to lead: today's leaders replicate the poor leadership habits they have observed in others, today's leaders often lack basic skills for common leadership demands, today's leaders lack good models and mentoring, today's leaders lack formal training in leadership and finally today's leaders suffer confusion over the conflicts between secular and biblical leadership (ethical values), (Finzel, 1994).

How does this apply to Uganda and Eastern Region in particular? Is it true for all functioning institutions? What is the situation in Eastern Region? What challenges leaders of HILs in Eastern Region are facing? What lacks are HILs exhibiting that could hinder them to be catalysts of effective school leadership in the Region for a holistic development that needs to take place?

\section{Involvement in Formulation of education policies}

The current education systems in Uganda and Africa in general were borrowed from Western models from colonial times. Previously, people went to schools so that upon completion of their studies they will join jobs waiting for them. In other circumstances because of the needs foreseen by government or different non-government organizations, selected people were sent to schools and were encouraged to come back to serve.

Samoff \&Budemi (2003) support, Although Africa boasts a tradition of indigenous and Islamic higher education institutions that predate western colonization, the roots of nearly all of the modern higher education institutions in Africa can be traced back to the colonial period and to external support from varied sources. Education was among the tools colonial governments used to manage society and channel social change, a process in which the church often played a major role. By 1816 the Church Missionary Society had established a Christian institution in Sierra Leone for training clergy, which in 1827 became Fourah Bay College, the first institution of higher learning in sub-Saharan Africa. By the end of the 19th century, critics including educated African elites, challenged the clerical focus and called for publicly financed African universities that would emphasize science and technology or provide a liberal education. It was not until after the First World War that colonial governments started to develop official policies for the provision of high education in Africa. The general pattern was to create institutions in Africa as satellites of European universities, which retained responsibility for staff appointments, curriculum, examinations, and degrees.

Africans were not involved in policy formulation whereas Involvement in the formulation of policies is one of the key expectations of any leader especially the leader in charge of a higher institution of learning. Marton (2006) says:

It is hard to ignore today that the role of education in our societies is taking on increased importance. The term" knowledge society" has become a common phrase for most citizens, heard almost daily in the 
media, in the school corridors and promulgated by our politicians. Education is now viewed as the key component to economic competitiveness in an increasingly global world.

It is the role of any leader of any institution of higher learning to stress the role education can play in our societies today. Technology and communication have seriously impacted the way we speak and do. The current trend of life is based on those two. Knowledge about technology and communication is crucial for any development to take place. Education policy for this century must have at its center knowledge, knowhow to do things (hands-on knowledge) to remain competitive. Job opportunities and job creation rely completely on that. The World Bank influence has been both direct and indirect. Much of that influence has come in the form of technical assistance and efforts to shape the development of higher education policy (Samoff \& Bidemi, 2003). HILs are educating students who are called to meet the expectations of this $21^{\text {st }}$ Century. One of the expectations is that education should lead to sustainable development. UNESCO (2009) indicates:

The Millennium Goals for Development (MDGs) provide a universal framework for development, agreed to by all UN Member States in 2000. They provide a means for developing countries and development partners to work together in pursuit of a sustainable future. Education for sustainable development (ESD) can contribute to the achievement of all the MDGs. It can help governments and development partners to ensure that capacity exists for achieving the MGDs. ESD provides learning goals that help achieve the MDGs. Thus, there is a call to revisit current education programs that are developed based on western models. With globalization, and speed with which technology and communication are developing, it is more than urgent to rethink current existing policies and formulate new policies that address the demands of the century.

The MDGs include the following: eradicate extreme poverty and hunger, achieve universal primary education, promote gender inequality and empower women, reduce child mortality, improve maternal health, combat HIV/AIDS, malaria and other diseases, ensure environmental sustainability, develop a global partnership for development.

Unemployment, poverty, and other social vices such as drug and alcohol addictions are stumbling blocks for true development to take place in this century. Thus, education policy should address those by developing empowering policies for total transformation of both individuals and communities. HILs are the laboratories where the minds of people can easily be shaped and molded to allow both students and individual members of communities to usefully use their full potentials through the opportunities that those institutions can offer. Therefore, education curricula should be planned to create an intention to act positively for development. This development should lead to sustainability, hence self-reliance which must be for self and for. There is a need to train for action as again UNESCO has stressed Education, leadership, and development are key ingredients of sustainable development. For this to be possible, we need MGDs to be followed. One of them underlines action competence. UNESCO (2009) puts it, "Developing action competence of leaders, politicians and youth groups for service delivery and work (MDG 8)." UNESCO posits that education for sustainable development is needed to develop action competence for improved natural resource management. This is a critical learning goal for developing countries, if they are to meet MDCs 1, 3 and 7 simultaneously (ibid). Samoff \& Bademi (2006) declare.

But most of Africa's strained economies cannot expand education's share of the total budget. Even where that share grows, declining total revenue may still reduce spending on education. In these circumstances, available resources will reach far more students at the bottom than at the top of the education pyramid. That general argument is then supported by research that reports higher social rates of return for investment in basic education and high private benefits for higher education. The redirection of resources can thus be presented as necessary, sound financial policy, and eminently fair.

All that cannot be significantly done if HILs are not involved. The leadership of HILs with clear vision should be at the forefront of policy formulation since they have necessary information to share with decision makers. Leaders of HILs master opportunities they can offer to students, staff, and community. Involving 
DOI: 10.21522/TIJAR.2014.SE.19.01.Art007

ISSN: $2520-3088$

them in the formulation of educational policy and their related bylaws will allow HILs to be efficient catalysts of sustainable development.

\section{Methodology}

In line with this, this research study mainly used the qualitative research approach in the search of data to solve the problem. The purpose of selecting qualitative methodologies was two-fold: to collect information from individual perspectives of the needs that are associated with the exploration of opportunities, potentials in HILs and determine challenges that leaders face in their effort to lead HILs; to determine whether HILs are involved in the process of policy and bylaws formulation at both national and district levels. In-depth Interview and Focus group discussions were chosen as techniques to collect useful data.

\section{Population of the study and sampling techniques}

Participants of this study were selected from the 30 HILs that have been established in the eastern region of Uganda that stretches from the Nile River to the boarder of Kenya. The study targeted leaders who play key roles of leadership and development in HILs from the GP to lecturers, Deans and Top administration. The non-probability sampling was used. Kothari (2014) points out that under non-probability sampling, the organizers of the inquiry purposively choose the particular units of the universe for constituting a sample on the basis that small mass that they so select out of a huge one will be done at their convenience.

\section{Results}

All who responded were mature and their ages varied between 20 and 60 years old. All were Female and male leaders. Selected institutions were public and private institutions of higher learning. Participants agreed that in higher institutions of learning are the following opportunities, Potentials, Challenges. They also indicated what was their opinion on the level of involvement between them as leaders of HILs with the ERLG.

\section{Opportunities}

\section{Opportunities for students}

Change of mindsets of both students and staff as well as community, instill the desire to be a change agent, training for training others and not for selfish ambition, promotion of globalization, modernization of traditional systems of production, learning and employment opportunities, revisit existing training materials and adapt it to the expectations of the $2^{\text {st }}$ century, counseling and economic empowerment for betterment of life, networks between people of different cultures, opportunity to demystify the illusion of the white color job after graduation, possibility of job creation, training and practice of leadership, technological know-how, problem solving through research, skill-based education, alumni associations for networks and job creation, cooperation with other institutions of learning, training for leadership exercise, sharing of resources with sister institutions, partnership opportunities at both national and development levels, implementation of policies, accessibility to study (talent based), exposure to existing jobs in both national and international markets, training for expert skills, generational gap: is an opportunity for appropriate leadership training and transition between the younger and older generations, rethinking of curricula for more relevance, exchange programs between students from developed and developing countries, preparation for change of mentality for destiny ownership, sensitizing students on globalization and consequent competition and develop strategies to cope up with the expectations, exposure to practice knowledge before graduation and begin participating in the shaping of society, skills for service delivery, network opportunities with alumni, career development from experts from different disciplines, internship placement, personnel development in all areas, holistic education for development, opportunities as eye openers to the outside world, acquisition of appropriate knowledge to challenge the current political dynamics in our midst, bring education to individuals and communities, opportunities to fight poverty 
through knowledge, know-how, and attitude change, exchange programs between students from different HILs.

\section{Opportunities for community}

Opportunity for appropriate education that goes with the needs within the community thus community empowerment, scholarship for the needy students, community education for community engagement and ownership, security opportunities of communities through electrification, empowerment of the poor and other vulnerable members of the community, project development for community services, infrastructure development for the community, employment for community members, scholarship for communities, giving hope and skills to the community, ability to solve individual and community problems, education for vulnerable people, advocacy and lobbying for community development

\section{Opportunities for both students and community}

Higher Institutions of Learning do offer platforms to change the mindsets of both students, staff as well as members of the community, mentoring, sponsorship, exposure to politics that can lead to the promotion of sustainable development, eradication of the dependency syndrome, developing of a saving culture for self-reliance, enhancement of initiatives for social cohesion, exposure to different cultural values, traditions, customs and norms, formation of associations for different purposes, development of individual and community according to the potential they have, promotion of technology because society is shifting, training for entrepreneurship, training for work for general interest and avoid selfishness, exposure to globalization and its impact of students, staff, and communities, empowerment for decision making, incite students, staff, and community to love working, practical knowledge (industrial training), opportunity for self-expression, network opportunity for students, staff and communities, sense of community ownership of HILs, social cohesion, communication opportunities, platform to grow in responsibility, development and implementation of policies to harmonize work and education, knowledge generation.

\section{Potentials}

\section{Potentials in relation to students}

Students have natural talents (abilities) to be used by leaders in HILs (sport, students connections through networks with different families, organizations and potential employers, organizations sponsoring students, manpower for development (work force), innovation and invention (renewing and improving what already exists), experimentation of theoretical knowledge, organize workshop and promote research, prior knowledge of the community, training people and pruning them for effective leadership, capacity to give out services to universities (students with already existing businesses), potential for international adventure, character and attitude shaping, values and traditions are potentials for sustainable development. people are defined by their cultures and traditions as well as other determinants such as activities they are involved in, associations and clubs for development, guest/motivational speakers (eye opener for personal talents discovery or diagnosis) on real life stories and opportunities, holistic development focusing on the head, heart, and hand, leadership exposure, study tours in various fields and learn from them, marketing opportunities for hils through co-curricular activities, increase enrolment through community services, promote self-image and confidence, center for sharpening skills, potential to promote team work, potential to market the university.

\section{Potentials for community}

Natural resources, local manpower, security, community influent people (traditional, religious and administrative and political leaders), employment for the best and needy students (equipping them with skills), business empowerment, mechanization of labor to increase productivity. 
DOI: 10.21522/TIJAR.2014.SE.19.01.Art007

ISSN: $2520-3088$

\section{Potentials for both students and community}

Capacity building for good governance, relationship building, relationship for fostering more social cohesion and development, promotion of technology, involvement with political leaders, cultural leaders, students' talents, promotion of research for community empowerment, exclusive periods and places for practicals, cooperation and partnership for shaping the younger generation, potential for leadership training and delegate authority, reduce the gap between the young and old generations through sharing of practical experience for empowering the young to face the future, exposure to community members opinions for more ownership, potential to design adequate curriculum for the promotion of self-reliance and fight dependency for Africa is more internally and externally dependent, lobbying opportunity, needs within the community.

\section{Challenges}

\section{Challenges in relation to students}

Change of the mindset, laisser-faire mentality, inadequate funding, inadequate pay for education professionals therefore most lecturers tend to moonlight to boost their income, training is not complete therefore half-baked products, low income of higher institution of learning does not help the smooth running of the institution, poor relationships between lecturers and students, lecturers and lecturers and students, unemployment becomes a threat to enrollment, ignorance is the big obstacle to development, political dynamics make education look like a threat, understaffing, lack of education facilities, dropping in enrolment, quality of education is decreasing, mismatching of policies: two different ministries handling institutions' issues such as salary, discrepancy between government involvement and HILs: public institutions are not treated equally with the government and yet they are called to work hand and in hand in order to boost the government in its effort to push education step forward, lack of clear mission and vision for some institutions, lack of training material for more practicals for students, lack of personal engagements: young people do not know what to do, generational gap, dependence mentality of young people, avoidance of work and use short cuts for wealth making, lack of the teamwork mentality, selfishness and lack of know-how of the dynamics, young people want payment and good life before work, administration is also a stumbling block sometimes, lack of self-vision and confidence, trust and mistrust among students and administration, insecurity (bushy environment, lack of lightning arresters), strike threats in HILs, dictatorship approach to leadership, context of operations in institutions does not favor resourceful people, inability to improve salaries thus high turnover of personnel, unclear governance structure which leads to poor management of HILs, low enrolment (why should i go to school if graduates are lacking jobs), poverty level is high (inability to pay tuition), communication between institutions and the government leaders, gap between gained skills and practicing those skills (gap between theory and practice), lack of tracing of graduates to see whether knowledge into practice, commercialization of educational institutions (profit oriented) which affects quality of education, striking balance between students' needs and institutions ability to deliver to the satisfaction of students, staff, and communities, religious, administrative, and political discriminations on campus or country, lack of opportunities for students to exhibit their full potential, massive brain drainage to foreign job opportunities especially to the west and east, communication gaps between local government and higher institutions of learning.

\section{Challenges related to community}

Traditions and values, resistance to change, institutions not involved in discussions concerning sustainable development, terrorism is hindering institutions' efforts for development, poor self-image: there are people whose self-image is poor. they think others must respect them, accumulated deficiency of the youth, freedom and erosion of values, dependency mentality, leaders sticking on to power for long, government leaders do not understand the needs of leaders of HILs, inadequate ratio between key factors: students and staff, some communities are not open to education, lack of platforms to sharpen skills, new curriculum is challenging to staff since it calls for extra funds and yet money is not there, illiteracy is high 
in some villages and the poverty level is very high, gender imbalance, the pace of development in technology and communication so fast that institutions have to struggle to catch up, communication gaps between institutions especially HILs and local governments, land wrangles, lack of open communication between leaders, benefactors of development, and communities, people in community do not want to work, human rights mentality is causing social disconnection, lack of positive legacy for the young generation, colonialism, post colonialism, neo colonialism, the roles of universities are kept in the drawers of decision makers, difference in leadership styles leading to the wrong perception of the managers at different levels of social interaction, lack of role models, technology is changing unemployment, resistance to change, communication gaps between top leaders and middle-level leaders, lack of cooperation between local leaders and institutions, gap between the rich and the poor, lack of appropriate research vis-à-vis community needs, qualification of staff is doubted wrong sense of community ownership, lack of unity between community and institutions', lack of true partnership between institutions and communities, political dynamics affect day-to-day operations of higher institutions of learning, lack of planned meetings between local governments and higher institutions of learning.

\section{Challenges related to students and the community}

Lack of benchmark with other institutions, taxation, high expectations of students, staff, and communities, fraud and forging of receipts, lack of resources, perception of leadership, misconception of leadership concept, exposure to high risk such as fire, types of communities (some are aggressive), donor fatigue, abusive rewarding systems, poor time management, communication gaps between senior management and the students in some institutions, lack of transparency and accountability between leaders of institutions and student leaders, globalization, competition between institutions, higher expectations from the leaders, limited resources to do work, lack of emotional support, conflict management, struggle to remain competitive, lack of truth telling between students, staff, and communities, wrong job expectations for both students, staff, and community, research unfunded, yet it is one of the three mandates of any university, lack of parental follow up, interaction gap between leaders, laziness in the community, embezzlement of funds, misuse of property, corruption, tribalism, cultural discrepancies, racism, gender imbalance, nepotism, higher institutions of learning are not listened too when discussing development issues, inexistence of memoranda of understanding between higher institutions of learning and communities and or other existing bodies necessary for development.

Objective 4: Level of involvement in Discussions on Development Issues between leaders of HILs and Leaders in Eastern Local Government

\section{Involvement with local government}

In Uganda, policies are developed by the Government and related bylaws are formulated at local government in the Districts. Participants responded that HILs should be involved in the formulation of both policies and bylaws related to development issues. This is important for HILs to fulfill their mandate of imparting knowledge, conduct research and offer community services to the people of communities where they are established. Unfortunately, that is not the case as responses in this study show. Findings revealed that there is no much involvement between leaders of higher institutions of learning with those with local governments in eastern region. Out of $30 \mathrm{HILs}$, respondents from only 3 institutions (1\%) supported that there is a sort of involvement although HILs try to have local leaders as members of higher institutions governing bodies especially at University Council and Board of Trustees levels. The remaining 27 institutions visited representing 99\% higher institutions of learning visited indicated that the level of involvement in local government issues is very low and even when they get involved most of the time meetings are unplanned. A respondent said, "they do come when they need their taxes to be paid." This view was given by students and staff. Communities get involved only when there are projects that are initiated by the government. Times often, projects are initiated from national level and not at grassroot level. 
DOI: 10.21522/TIJAR.2014.SE.19.01.Art007

ISSN: $2520-3088$

\section{Discussions and summary}

The researcher referred to Guvstavson (2016) who says, "When you focus on your mission and stay mindful of your purpose, you can adjust to new and exciting vision opportunities." Leaders of HILs should adhere to this statement. It is difficult to cause development without a mastery of mission and vision and the sense of purpose. Leaders of HIL should remain vigilant on new developments and discover opportunities that are there in HILs and outside HILs and which can be used during learning. In fact, as students join HILs, they expect to be exposed to knowledge, acquire skills and, they want to be exposed to existing job or even be empowered to use their skills so that they create jobs for themselves and even give employment to other members of the communities where they live. Equipping them for that will enable graduates to look for jobs but also since jobs are rare to the African graduates as pointed out, these graduates after acquiring appropriate knowledge and skills could start their own business and reach the final goal for this century: using education for sustainable development.

For today and tomorrow's society, we need leaders with clear vision. This is critical for leaders in higher institutions of learning in the world or Africa. Education should have a clear mission, purpose, and a clear vision if it should be the drive of sustainable development. In relation to this, Musaazi (2011) pointed out in chapter two that development is an educational process. Any leader in HIL must have the vision of leading graduates to sustainable development as training goes on not only by exposing students to opportunities but enable them to grasp these opportunities to make them useful citizens who will help them not only to induce but also to maintain and promote sustainable development. In the preceding section, opportunities were given. They should be used to cause development.

Each group of people has its own values and traditions. This affect both institutions (HILs included) and these values and traditions lead to definitions of a kind of organizational philosophies, missions and vision. These enables the definition of individual identities that lead to self-image. Those values and traditions when positive, they are crucial factors to consider for development: hard work, courage and determination are values. The researcher supports that if properly used, they will allow both individuals and communities to move forward. All these elements are key ingredients of self- image and can increase confidence and trust in self for more intentional action. In connection to this one of respondents gave the example of men in the Massai communities. He said that "the Massai people are known of their tradition of being able to kill lions. They are known to be fearless and capable of facing challenges courageously." Development is a very ambitious call. To achieve sustainable development, courage and determination combined with hard work are indispensable on the road to development because with development many challenges come: resistance to change because people want to remain where they are as they are. To cause a change of mentality is not an easy task.

Findings also revealed that there are lots of potentials for both students, staff and communities. It is now for the leaders of HILs to let students, staff and communities discover their full potentials. Once exposed to them they will have to use them and build onto them to make them able to become important participants in critical discussions and then after useful participants in the efforts to promote sustainable development.

The findings in this study have shown that there are many opportunities that are there for students and staff as well as communities in which HILs have been established. The youth population in Uganda is the youngest in Africa. As this youth is educated, they have a lot of expectations from the government and the families where they come from. They need jobs, unfortunately the VCF (2016) revealed that out of 400, 000 students who graduate every year as, only one third of graduates get jobs. What about the remaining two-third? If nothing is done, then they become unemployed and can easily embark dragged in activities that make them become threats for sustainable development instead of being catalysts of true development. They become preys to drug and alcohol consumption. Most of them get involved into criminal activities and become perpetrators of other social vices capable of engendering a cycle of crimes, misery and poverty altogether.

In regard to this and According to the UBOS 2014, Uganda has a population of 34. 85 Million. Life expectancy in Uganda is 58.65 years (https://www.google.com/\#q=uganda+population). It is also known 
that the Ugandan population is dominated by youths representing around $78 \%$ of the total population as initially pointed out. These statistics are very significant for school leadership in both public and private HILs. In them lies a great potential for school leadership empowerment on which depends the future of the education sector for integral development of Uganda as a country in general and Eastern Region in particular. There is potential for positive influence as far as leadership is concerned even though unemployment can be considered as a social threat by many. These youth have potential that needs to be analyzed politically, economically, socially, culturally and assess all possible means of empowerment which can lead such a population to be very productive. Uganda can capitalize on that to induce development that the final goal will be sustainable development, hence self-reliance.

Any research leads to findings that need to be critically looked at and compared to existing knowledge. The review of literature informed on opportunities and potentials that exist in Higher Institutions of Learning. This section also pointed out existing challenges that hinder leaders of Higher Institutions of Learning to play their key role of being catalysts of sustainable development. Participants in this research have clearly pointed out existing opportunities, potentials and challenges as we presented them in chapter four. They also indicated what they think could help promote sustainable development as established for this $21^{\text {st }}$ Century.

Musaazi (2006) indicates that to make education a profitable enterprise and a contributor to social development, planning must come to be accepted as the essential prerequisite. The researcher agrees with Musaazi. Now that opportunities in HILs are known as well as potentials and challenges, there is a need for proper educational planning so that school programs will offer not only knowledge but also platforms for practical application of the acquired knowledge. This will enable leaders of HILs to have a great impact on the lives of students after they graduate for, they will somehow able to have enough confidence through acquired knowledge the how to use the knowledge and be able to be creative and innovative. With these practical skills, unemployment and issues of poverty can be addressed accurately and lives can be improved, through economic empowerment which is the backbone of sustainable development.

The researcher through the outcomes of this study reveals that there is no way self-reliance will be attained if there is no intentionality to action that needs to be talked about from the very beginning of the education process of the learner. Intentional action needs to be at the center of any education endeavor if we need to speak more about pragmatic leadership. That's why he sought to expand a step further that existing theory and establishes therefore a new theory that he calls Pragmatic Leadership Theory with Intentional Action (PLTIA). This new theory is represented in the following diagram:

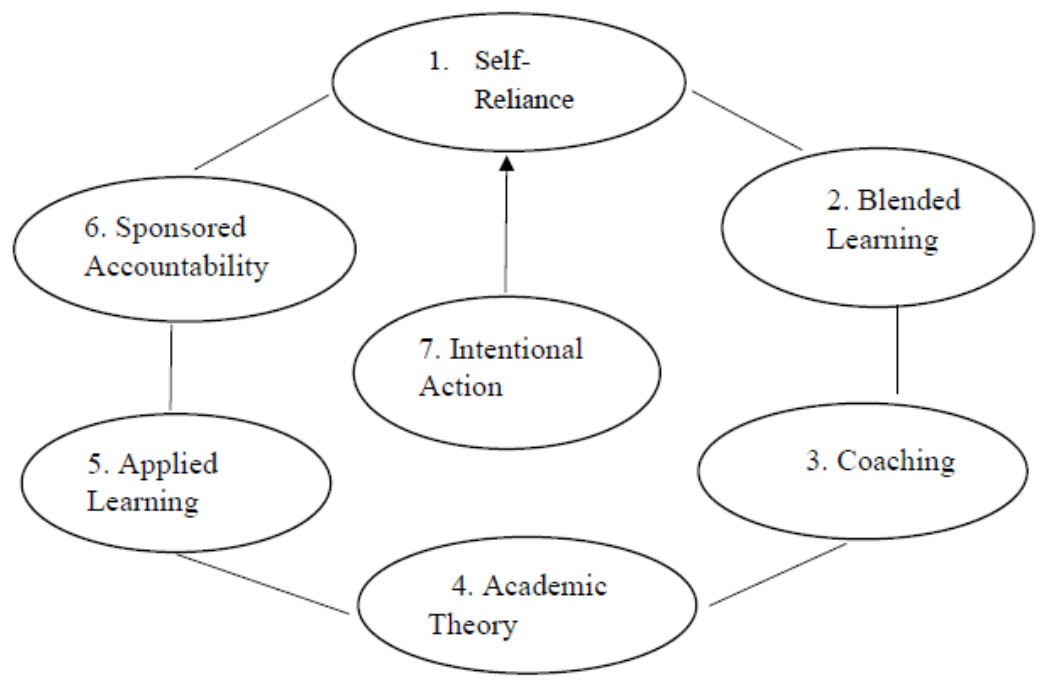

Figure 5.1. Pragmatic Leadership Theory with Intentional Action (PLTIA) 
DOI: 10.21522/TIJAR.2014.SE.19.01.Art007

ISSN: $2520-3088$

\section{Conclusion}

To conclude, the researcher builds on Pragmatic Leadership Theory to propose a new theory that he calls Pragmatic Research Theory with Intentional Action. The study has revealed that many opportunities and potentials that exist in HIL which if well used will make HIL indispensable catalysts for sustainable development. This type of development is based on Intentional Action that will absolutely lead individuals to self-reliance. Africa as a continent has people and resources and it is a paradox to talk about resources and poverty or unemployment. This remains true for Uganda and Eastern region as well. It is time to wake up and suggest a new educational approach that will cause Africa to reach Sustainable development as expected in this 21st century. In fact, the millennium goals for development speak about education for sustainable development as pointed out earlier. For the researcher, it is unworthy to speak about selfreliance if the education curricula from home to schools at different levels of education do not stress intentionality to Action for self-reliance. And this self-reliance is not for selfish ambition but for selfempowerment and the empowerment of other members of the community.

\section{Implications of the study}

The findings and results had different implications: Opportunities and potentials do exist in Higher Institutions of Learning. Therefore, there is a need to review leadership at HILs' level and try to unveil their weaknesses to avoid producing half-baked graduates who cannot be employed because they do not fit with the needs of society. The education system needs to be revisited so that Pragmatic Leadership Theory with Intentional Action be considered as the best educational approach that can help cause sustainable development.

\section{Directions for future research}

The research study has been conducted only in the Eastern Region of Uganda, there is need to expand it to other regions in the whole country and if possible, someday on the whole continent. The quantitative approach with the use of descriptive and inferential statistics could then be used to compare livelihood of those who benefit from PLTIA versus those who continue to study under the traditional educational approaches and see which group is better.

\section{References}

[1]. Ali, G., Haolader, F.A., Muhammad, K (2013) The Role of ICT to Make Teaching-Learning Effective in Higher Institutions of Learning in Uganda in International Journal of Innovative Research in Science, Engineering and Technology (An ISO 3297:2007 Certified Organization, Vol. 2, Issue 8, August 2013, ISSN: 2319-8753.

[2]. Aubel, J. (1994) Guidelines for Group Studies Using the Group Interviews Technique. Geneva: ILO.

[3]. Baker, M.J. (1998) Macmillan Dictionary of Marketing and Advertising. $3^{\text {rd }}$ Ed. London: Macmillan Press Ltd.

[4]. Barasa, G. (2016) The Influence of School leadership on Students' Academic Performance in Selected Secondary Schools in Busia District, Uganda.

[5]. Blackaby, H. \& Blackaby, R. (2001) Spiritual Leadership. USA: Nashville: Broadman \& Holman Publisher. Bolden, R., Jones, S., Davis, H. \& Gentle, P. (2015) Developing and Sustaining Shared Leadership in Higher Education. Leadership Foundation for Higher Education. Retrieved from http://www.Ifhe.ac.ug. Brill, F.S. (2008) Learning and Leading: Effective School Leadership through Reflective Storytelling and Inquiry. USA: Stenhouse Publishers.

[6]. Carter N., Bryant-Lukosius D., Dicenso A, Blythe, J., Neville A. J. (2012) The Use of Triangulation in qualitative research, https://www.ncbi.nlm.nih.gov/pubmed/25158659:

[7]. Cooper, A. \& Potter J. (2001) Intelligent Leadership: Creating A Passion for Change. London: Random House Business books. Cornerstone Leadership Academies (2013). Retrieved from www.CornerstoneSchoolsAfrica.org English, F. W. (2015) The SAGE Guide to Educational Leadership and Management California: SAGE Publications, Inc. 
[8]. Finzel, H. (1994) The Top Ten Mistakes Leaders make. USA: Victor Books/SP Publications, Inc. Goldstein, K. L., Miller, A. \& Courson, J. (2014) Reinventing Leadership in Higher Education: A confidential survey of College Presidents. Retrieved from http://www.witkieffer.com.

[9]. Gustavson, P. (2016) Leaders Press On, Discovering the Power of Perseverance Virginia: Lead Edge Press.

[10]. Harvard University (2012) Decision Making for Leaders: A Synthesis of Ideas from Harvard University Advanced Leadership Initiative Think Tank.

[11]. Hebert, E. A. (2006) "The Boss of the Whole School" Effective leadership in Action. New York: Teachers College Press.

[12]. Hopper \& Potter (2001) Intelligent Leadership. USA: Random House Business books https://www.csrmatch.org/project/transforming-communities-initiative-in-mbale-district-Uganda

Https://www.google.com/\#q=uganda+population.

[13]. Hughes, R. L., Ginnet, R. C. \& Curphy, G. J. (2015) Leadership: Enhancing the lessons of experience, $8^{\text {th }}$ Ed.: New York: McGraw Hill Education.

[14]. Jain, G., L. (1998) Research Methodology: Methods, Tools, and Techniques. New Delhi: Mangal Deep Publications. Kaahwa, M.G. (2008) Research Methodology: Made Simple. Kampala (UG): Sure, Technical Association Ltd.

[15]. (2007) A Search Engine For leaders, communicators, Researchers, and Educator in Research, Communication, Leadership, And Instructional Methods. Kampala: Sure, Technical Association Ltd.

[16]. Kanyeihamba, G., W. (2013) Universities in a Rapidly Changing Africa: Influence of University Education on State Governance. UVCF Publisher, UVCF Bulletin, Volume 2, ISSN: 2306-6288.

[17]. Kayiwa, B. (1997) Assessment of Leadership Training of Head Teachers and Secondary School performance in Mubende District, Uganda. Kyambogo University (BA Research Thesis), Unpublished.

[18]. King, K. (2004) The External Agenda of Educational Reform: A Challenge to Educational Self-reliance and dependency in Sub-Saharan Africa. Centre of African Studies, University of Edinburgh. CICE Hiroshima University, Journal of International Cooperation in Education, Vol 7, No.1, (2004) pp. 85.

[19]. Kipkurgat, T. K. (2006) Agricultural Science Curriculum for Messiah Theological Institute $\quad$ in $\quad$ Mbale, Uganda: A Ph. D. Dissertation.

[20]. Klees, S. J. World Bank Development Policy: A SAP in SWAPs clothing. Current Issues in Comparative Education, 3 (2) ... article. USA: Columbia State University.

[21]. Kornfield, D. (1989) Church Renewal: A handbook for Christian Leaders. USA: Baker Book House. Kumar, R. (2011) Research Methodology: A step-by-step guide for beginners, $3^{\text {rd }}$ Edition. London: Sage Publications Ltd.

[22]. Krueger, R.A. (1988) Focus Groups: A Practical Guide for Applied Research: Newbury Park: Sage Publications. Inc.

[23]. Leithwood, Anderson \& Wahlstrom (2004) Learning from leadership project: Review of research: How leadership influences student learning. Minnesota, Center for Applied Research and Educational Improvement.

[24]. azrui, A. A (1979) Churches and Multinationals in the Spread of Modern Education: A third World Perspective, Third World Quaterly, Vol. 1 (Jan. 1979), pp. 30-49.

[25]. Marton, S. (2009) "Education Policy." Handbook of Public Policy. Sage Publication. Retrieved from http://sageereference.com/hdbk_pubpolicy/Article_n14.html> Mbabazi, P., Nanyonga, C. (2013) Reforming Uganda's Education for Quality and Employable Graduates. UVCF Publisher, UVCF Bulletin, Volume 2, ISSN: 2306-6288.

[26]. Musaazi, J.C.S (2011) Planning and Development in Education. New York: Routledge (2006)

Educational Planning. Kampala: Makerere University Printery.

[27]. NCHE (2011) Quality Assurance Framework for Institutions of Higher Learning. Kampala (UG): NCHE.

[28]. Pragmatic Leadership (2014) Pragmatic Leadership. Retrieved from Http://www.pragmaticleadership.ca. Online publication, Cognascent, Inc.

[29]. Ogden, G. \& Meyer, D. (2007) Leadership Essentials: Shaping Vision, Multiplying Influence, Defining Character. Illinois: Intervarsity Press 
DOI: 10.21522/TIJAR.2014.SE.19.01.Art007

ISSN: $2520-3088$

[30]. Samoff, J. \& Bidemi, C. (2003) From Manpower Planning to Knowledge Era: World Bank Policies on Higher Education in Africa. UNESCO Forum Secretariat hivambu, F. (2015). The crisis in higher education is a crisis of political leadership. South Africa: Daily Maverick (2017) $21^{\text {st }}$ January 2017.

[31]. Sommer, B. \& Sommer, R. (1997) A Practical Guide to Behavioral Research: Tools and Techniques. $4^{\text {th }}$ Ed. New York: Oxford University Press. The Wallace Foundation (2016) School Leadership. New York: The Wallace Foundation.

[32]. Topping, P. A (2002) Managerial Leadership New York: McGraw-Hill (Business) Inc.

[33]. Turner, J.J. (1982) Christian Leadership Handbook: How to be Worth Following. Texas: Fort Worth, Quality Publications.

[34]. The Guardian (2014) Global Development-Why is east Africa facing a hunger crisis and what can be done? podcast, Retrieved from https://www.theguardian.com/global development/2014/Jan/16/Uganda - unemployedgraduates-held-back-skills-gap.

[35]. Uganda Bureau of Statistics (2014) National and Population Housing Census, Revised Edition Uganda, UBOS. Retrieved

from

http://www.ubos.org/onlinefiles/uploads/ubos/NPHC/NPHC\%202014\%20PROVISIONAL\%20RESULTS\%20REP ORT.pdf.

[36]. UNESCO (2014) Roadmap for implementing the global action program on education for sustainable development. Paris: UNESCO.

[37]. UN System Task Team on Post 2015 UN Development Agenda (2012) Technological learning and innovation capacity: a cutting-issue for inclusive development (Science, technology and innovation for sustainable development in the global partnership for development beyond 2015).

[38]. Yang, R. (2003) Globalization and Higher Education Development: A Critical Analysis. International Review of Education 49 (3-4): 269-291, 2003. Netherlands: Kluwer Academic Publishers. Youssef, M. (1986) The Leadership Style of Jesus: How to develop the Leadership Qualities of The Good Shepherd. USA: SP Publication, Inc. 